\title{
Using Bioactive Glasses in the Management of Burns
}

\author{
Saeid Kargozar $^{1 *}$, Masoud Mozafari ${ }^{2,3,4}$, Sepideh Hamzehlou ${ }^{5,6}$ and Francesco Baino ${ }^{7 *}$ \\ 1 Tissue Engineering Research Group (TERG), Department of Anatomy and Cell Biology, School of Medicine, Mashhad \\ University of Medical Sciences, Mashhad, Iran, ${ }^{2}$ Bioengineering Research Group, Nanotechnology and Advanced Materials \\ Department, Materials and Energy Research Center (MERC), Tehran, Iran, ${ }^{3}$ Cellular and Molecular Research Center, Iran \\ University of Medical Sciences (IUMS), Tehran, Iran, ${ }^{4}$ Department of Tissue Engineering and Regenerative Medicine, Faculty \\ of Advanced Technologies in Medicine, Iran University of Medical Sciences (IUMS), Tehran, Iran, ${ }^{5}$ Department of Medical \\ Genetics, School of Medicine, Tehran University of Medical Sciences, Tehran, Iran, ${ }^{6}$ Medical Genetics Network (MeGeNe), \\ Universal Scientific Education and Research Network (USERN), Tehran, Iran, ${ }^{7}$ Applied Science and Technology Department, \\ Institute of Materials Physics and Engineering, Politecnico di Torino, Turin, Italy
}

\section{OPEN ACCESS}

Edited by:

Francesca Taraballi, Houston Methodist Research Institute,

United States

Reviewed by:

Antonella Sola,

University of Modena and Reggio

Emilia, Italy

Ahmed El-Fiqi,

Dankook University, South Korea

${ }^{*}$ Correspondence: Saeid Kargozar kargozarsaeid@gmail.com Francesco Baino francesco.baino@polito.it

Specialty section:

This article was submitted to Biomaterials,

a section of the journal

Frontiers in Bioengineering and Biotechnology

Received: 03 February 2019 Accepted: 07 March 2019

Published: 28 March 2019

Citation:

Kargozar S, Mozafari M, Hamzehlou S and Baino F (2019) Using Bioactive

Glasses in the Management of Burns.

Front. Bioeng. Biotechnol. 7:62. doi: 10.3389/fbioe.2019.00062
The management of burn injuries is considered an unmet clinical need and, to date, no fully satisfactory solution exists to this problem. This mini-review aims to explore the potential of bioactive glasses (BGs) for burn care due to the therapeutic effects of their ionic dissolution products. BGs have been studied for more than 40 years and boast a long successful history in the substitution of damaged tissues, especially bone. Considering their exceptional versatility and attractive characteristics, these synthetic materials have also recently been proposed in the treatment of soft tissue-related disorders such as skin wounds. Specifically, improving fibroblast proliferation, inducing angiogenesis, and eliciting antibacterial activity (with the additional advantage of avoiding administration of antibiotics) are all considered as key added values carried by BGs in the treatment of burn injuries. However, some issues deserve careful consideration while proceeding with the research, including the selection of suitable BG compositions, appropriate forms of application (e.g., BG fibers, ointments or composite patches), as well as the procedures for reliable in vivo testing.

Keywords: bioactive glasses, burns, wound healing, ion release, angiogenesis, antibacterial activity

\section{INTRODUCTION}

Burn injury is a frequent cause of morbidity and mortality over the globe. Based on a report published in 2016, about 486,000 patients in the US received medical care for burn injuries from 2008 to 2016; however, 3,275 of those passed away because of the severity of the injuries (Association, 2016). Based on the injury degree, a burn leads to several complications including infection, hypothermia, scarring, as well as bone and joint problems (Sevitt, 1979). Among the difficulties as mentioned above, bacterial infections are the leading cause of death (42-65\%) after extensive burn injuries (Sharma et al., 2006; Bloemsma et al., 2008; Keen et al., 2010; Krishnan et al., 2013). It has been shown that Gram-positive and Gram-negative multidrug-resistant (MDR) bacteria contribute to the burn infections in the first and late post-injury days, respectively (Lachiewicz et al., 2017). Therefore, the treatment of burns is of great importance, and the slow healing process and hypertrophic scarring are, in fact, unresolved challenges in burn research and management (Wang et al., 2018). 
After any burn, various therapeutic agents (e.g., antibiotics and silver-containing ointments) can be used in order to prevent infection from developing as well as to kill the actual microbial cells (see Table 1) (Dai et al., 2010). It has been noted that there is no need for the administration of prophylactic oral antibiotics in the case of minor burns since they may create multiresistant bacteria (Branski et al., 2009; Barajas-Nava et al., 2013). In this situation, antibacterial dressings can keep the bacterial colonization of wounds to a minimum (Hyland et al., 2015). Furthermore, it has been reported that the use of therapeutic substances that induce angiogenesis can lead to accelerating the repair and regeneration of burn wounds (Galeano et al., 2006; Oryan et al., 2018).

According to the criteria mentioned above, a feasible treatment approach that may fulfill all these requirements together and be actually and safely applied in the clinical practice still remain to be developed. In this regard, bioactive glasses (BGs) have been recently identified as promising substances for the management of soft tissue-related disorders. These synthetic biomaterials have been using for the treatment of acute and chronic wounds (Naseri et al., 2017; Kargozar et al., 2019). Releasing various therapeutic ions from BG structure into the biological environment is the main reason for their positive effects on wound healing (see Figure 1) and, more specifically, the great potential of BGs (as a topical therapy) could be exploited to treat burn injuries as many topical antimicrobial agents used for burns are cytotoxic to soft tissue cells (e.g., keratinocytes and fibroblasts), thus resulting in an unwanted delay in wound healing process (Lineaweaver et al., 1985; Barsoumian et al., 2013). The positive effects of BGs on the cells (e.g., keratinocytes) involved in better and faster healing of the burn wounds have been well-understood (Mârza et al., 2019), bringing new hopes in this important area of science.

After providing a general picture of the suitability of BGs in contact with soft tissues - with emphasis on "general" wound healing applications (section Attractive Properties of BGs for Soft Tissue Repair) -, this mini-review highlights the potential of BGs in the context of burn treatment (section Evidence of BG Suitability for Treating Burns). Since there is a paucity of studies specifically dealing with BGs for the management of burns, an effort was done in section Evidence of BG Suitability for Treating Burns-whenever possible-to underline the specific relevance of other reports coming from the broader field of wound-healing applications.

\section{ATTRACTIVE PROPERTIES OF BGS FOR SOFT TISSUE REPAIR}

After four decades from their invention, BGs have gained an important status in the biomedical field (Baino et al., 2018, 2019). They are routinely used for treating various diseases form

TABLE 1 | A short list of topical antimicrobial agents used for burn therapy.

\begin{tabular}{|c|c|c|c|}
\hline Agent class & Specific agent/Product & Application & References \\
\hline \multirow[t]{7}{*}{ Topical antibiotics } & Mafenide acetate & Clinical 2nd/3rd-degree burns & Haynes, 1971 \\
\hline & Bacitracin & Clinical 2nd/3rd-degree burns & Johnson et al., 1945 \\
\hline & Mupirocin & Clinical 2nd/3rd-degree burns & Palmieri and Greenhalgh, 2002 \\
\hline & Neosporin & Clinical 2nd/3rd-degree burns & Sinha et al., 1997 \\
\hline & Polymyxin B & Clinical 2nd/3rd-degree burns & Brown and Wood, 1972 \\
\hline & Nitrofurazone & Clinical 2nd/3 rd degree burns & Munster, 1984 \\
\hline & Nystatin & Clinical 2nd/3rd degree burns, fungal infections & Palmieri and Greenhalgh, 2002 \\
\hline \multirow[t]{8}{*}{ Silver } & Silver nitrate & Clinical 2nd/3rd-degree burns & Moyer et al., 1965 \\
\hline & Silver sulfadiazine & Clinical 2nd/3 rd degree burns & Fox, 1968 \\
\hline & Silver foams (Contreet, Allevyn) & Clinical 2nd/3 rd degree burns & Jørgensen et al., 2005 \\
\hline & Flammacerium & Clinical 2nd/3rd-degree burns & Monafo et al., 1976 \\
\hline & Acticoat 7 & Clinical 2nd/3 rd degree burns & Fong and Wood, 2006 \\
\hline & Aquacel-Ag & Clinical 2nd/3rd degree burns & Barnea et al., 2010 \\
\hline & Silvercel & Clinical 2nd/3rd-degree burns & Meaume et al., 2005 \\
\hline & Silver amniotic membrane & Clinical 2nd/3 rd degree burns & Sawhney, 1989 \\
\hline \multirow[t]{3}{*}{ Chitosan } & Hydrogel & Clinical 2nd-degree burns & Ribeiro et al., 2009 \\
\hline & Film & 2 nd degree burns in rabbits & Sezer et al., 2008 \\
\hline & Bandage & Mouse burn infections (Psuedomonas, Proteus) & Dai et al., 2009 \\
\hline \multirow[t]{6}{*}{ Antimicrobial peptide } & Defensins & In vitro & Ganz, 2009 \\
\hline & Demegel & Pseudomonas infected rat burns & Chalekson et al., 2002 \\
\hline & Histone H1.2 & Pseudomonas infected rat burns & Jacobsen et al., 2005 \\
\hline & Cecropin B & Pseudomonas infected mouse wounds & Ren et al., 2006 \\
\hline & rBPI & Clinical trial 2nd-degree burns & Steinstraesser et al., 2008 \\
\hline & Ceragenins & In vitro & Epand et al., 2008 \\
\hline
\end{tabular}

Reproduced with some modifications from (Dai et al., 2010). 

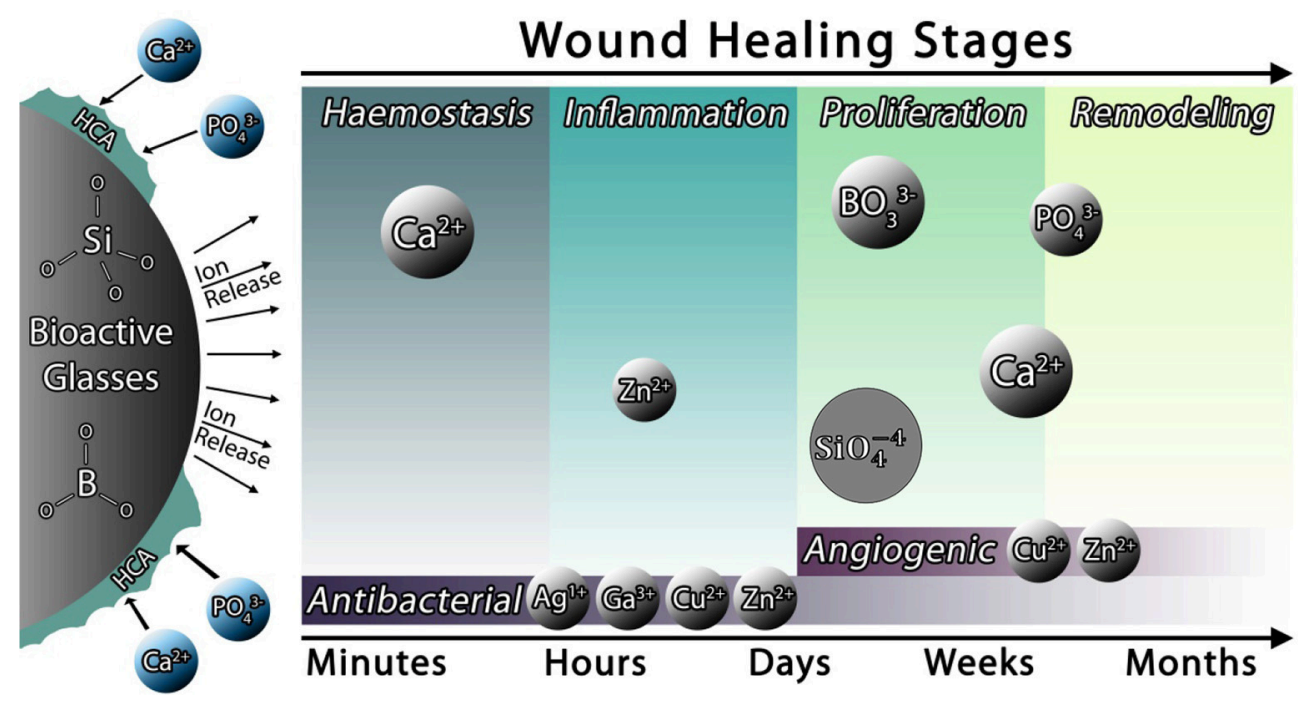

FIGURE 1 | The release of some metal ions from BGs into the surrounding environment has a positive effect on wound healing. Reproduced with some modifications from Naseri et al. (2017).

bone injuries to cancer metastases (Johari et al., 2016; Kargozar et al., 2016, 2017a, 2018d; Miola et al., 2019). The composition of the first BG developed by Prof. Larry Hench (melt-derived $45 \mathrm{~S} 5$ Bioglass ${ }^{\circledR}$ ) is based on a four-oxide system, $45 \mathrm{SiO}_{2}$ $24.5 \mathrm{Na}_{2} \mathrm{O}-24.5 \mathrm{CaO}-6 \mathrm{P}_{2} \mathrm{O}_{5}$ (wt \%), which has a high amount of $\mathrm{Na}_{2} \mathrm{O}$ and $\mathrm{CaO}$ as well as a relatively high $\mathrm{CaO} / \mathrm{P}_{2} \mathrm{O}_{5}$ ratio that makes the surface of the material very reactive in physiological environment. This reactivity provides the BGs with the capability of bonding to both hard and soft living tissues (Baino et al., 2016). Although the primary types of BGs (silicate glasses) were designed and used for hard tissue engineering, especially bone healing, the use of them for soft tissue healing has also been reported. As an illustration, Yu et al. clarified that pre-treatment of fibroblasts by a silicate BG could be an effective approach for the activation of skin tissue engineering constructs for improved wound healing ( $\mathrm{Yu}$ et al., 2015). The in vitro and in vivo experiments showed that BGs stimulate fibroblasts to overexpress some important growth factors and proteins (e.g., VEGF, bFGF, EGF, collagen type I, and fibronectin) which leads to (Association, 2016) an improvement in their migration ability, (Sevitt, 1979) an increment in the blood vessel formation, and (Krishnan et al., 2013) the differentiation of fibroblasts into myofibroblasts in the wound site. All the mentioned events, regulated via pretreatment with $B G$, resulted in an acceleration of wound healing process. Moreover, the efficacy of BGs for wound healing was shown at the molecular level as reported by Li et al. (2016b). They showed that $45 \mathrm{~S} 5$ Bioglass ${ }^{\circledR}$ ion extracts could prevent the death of human umbilical vein endothelial cells (HUVECs) following hypoxia, possibly through connexin hemichannel modulation. The positive effects of BGs on gap junction communication as well as the overexpression of connexin $43(\mathrm{Cx} 43)$ and other molecules involved in wound healing, e.g., VEGF and FGF, were also reported by the authors.

Recent advances have shown that new compositions of BGs (e.g., borate and phosphate glasses) can be applied for soft tissue healing (e.g., wound healing) as well (Naseri et al., 2017). Compared to silicate glasses, borate- and phosphate-based BGs exhibit some in vitro and in vivo behaviors (e.g., high dissolution rate) which are in favor of soft tissue applications and quick replacement with new tissue (Rahaman et al., 2011). In this regard, $\mathrm{Hu}$ et al. evaluated the efficiency of copper-doped borate BG/poly (lactic-co-glycolic acid) dressing loaded with vitamin E (0-3.0 wt.\%) for full-thickness wound healing ( $\mathrm{Hu}$ et al., 2018). The in vitro results clarified that the ions released from the dressings encouraged the migration, tubule formation, and VEGF secretion in HUVECs and fibroblasts. Moreover, the data obtained from in vivo experiments revealed a substantial improvement in the epithelialization of wound closure and a significant increase in vessel sprouting and collagen remodeling. The authors stated that the use of this composite biomaterial as a wound dressing could actually be a promise for accelerating the healing and reconstruction of full-thickness skin defects.

After being incorporated into the structure of BGs, some specific ions may be subsequently released and elicit beneficial biological effects such as improved cell proliferation (Xynos et al., 2000), inhibition of bacterial growth (Zhang et al., 2010), and stimulation of angiogenesis (Kargozar et al., 2017b) (see Table 2 and Figure 2).

For example, incorporation of silver ions $\left(\mathrm{Ag}^{+}\right)$into the glass structure imparts antimicrobial properties over various Gram-positive and Gram-negative bacterial strains (e.g., E. coli, P. aeruginosa, and S. aureus), without eliciting any toxic effect on human cells if silver is added under a threshold dosage (Miola and Verné, 2016). The release kinetics of therapeutic ions from BGs into the surrounding environment is determined by some factors such as the ionic radius of doping element, type of glass network, $\mathrm{pH}$ of the host environment, and temperature (Kargozar et al., 2018a).

As one of the most attractive types of BGs, mesoporous BGs (MBGs) are also considered as promising candidates for 
TABLE 2 | Therapeutic ions useful for soft tissue healing applications.

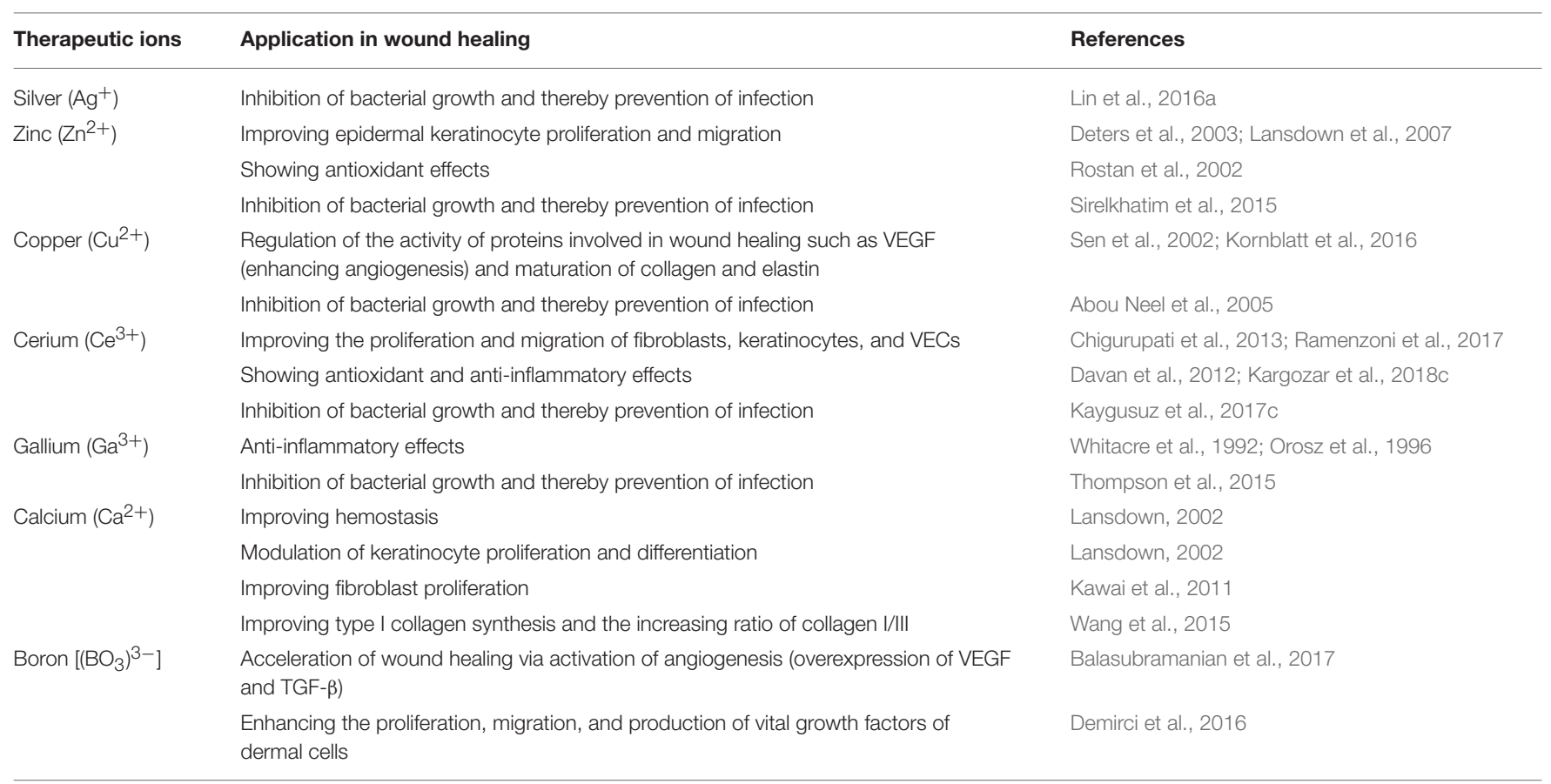

repair and regeneration of wound injuries (Wang et al., 2016; Kargozar and Mozafari, 2018). Experimental evidence showed that these materials could be used as suitable carriers for the controlled delivery of various therapeutic ions, drugs, and chemicals accelerating the healing process. The usability of MBGs have been previously well documented for antibacterial strategies (Gargiulo et al., 2013; Wu et al., 2013; Kargozar et al., 2018d) and angiogenesis-requiring applications (Dashnyam et al., 2017; Zhou et al., 2017; Romero-Sánchez et al., 2018). Also, Pourshahrestani et al. reported that galliumcontaining MBGs could improve hemostasis via stimulating blood coagulation, platelet adhesion and thrombus generations (Pourshahrestani et al., 2016).

In the context of soft tissue engineering, Wang et al. developed a biocomposite made of copper-containing MBGs and nanofibrillated cellulose (NFC) as a suitable dressing material for chronic wound healing application (Wang et al., 2016). They reported that this composite showed high bioactivity in simulated body fluid (SBF) and could act as a matrix for the sustained release of $\mathrm{Cu}^{2+}$ ions which inhibited the bacterial growth and improved angiogenesis in order to promote wound healing. Other MBG-containing polymer biocomposites like chitosan (CS)/MBG porous films have also been developed as promising wound dressing materials (Jia et al., 2011).

\section{EVIDENCE OF BG SUITABILITY FOR TREATING BURNS}

Generally, burns are categorized into four groups based on their depth and severity as 1st, 2nd, 3rd, and 4th degree. The extent of the injury is limited to only the epidermis in the first-degree burns, while it involves more layers of skin in the second-degree burns including the superficial (papillary) dermis and also the deep (reticular) dermis layer. The epidermis is lost, and damage to the subcutaneous tissue occurs in the case of third-degree burns; in addition to that, damage to the muscle, tendon, and ligament tissue are observed in the fourth-degree burns (Dai et al., 2010). It has been well documented that burns $>10 \%$ of total body surface area (\%TBSA) in children or $15 \%$ in adults are potentially life-threatening injuries as a result of the risk of hypovolemic shock (Malic et al., 2007).

A few criteria are typically counted for any medication used to treat or reduce the symptoms of burn injuries, i.e., attenuating inflammation, reducing infection, removing excessive exudates, and improving angiogenesis, thereby accelerating the healing process (Rowan et al., 2015). The promise of BGs in meeting these requirements is illustrated in Table 3. As previously mentioned, antimicrobial dressings are recommended for the management of minor burns (Hyland et al., 2015). However, it has been stated that there is no need for wound coverage if the skin is intact and not blistered. In this condition, the use of a simple moisturizer (e.g., silver sulfadiazine cream) has been recommended (Australian NZB Association, 2002). On the other hand, excessive or prolonged inflammation can result in impaired wound healing (Sommer et al., 2013). It is possible to prepare some compositions of BGs with the ability to reduce inflammation (Varmette et al., 2009) and bacterial infection (Coraça-Huber et al., 2014). As mentioned above, chronic inflammation is one of the main complications in patients with large burns which may impair wound healing (Ueno et al., 2005). The efficacy of 45 S5 Bioglass ${ }^{\circledR}$ on human macrophages and monocytes has been previously studied in vitro, showing its potential in terms of attenuating inflammatory responses 


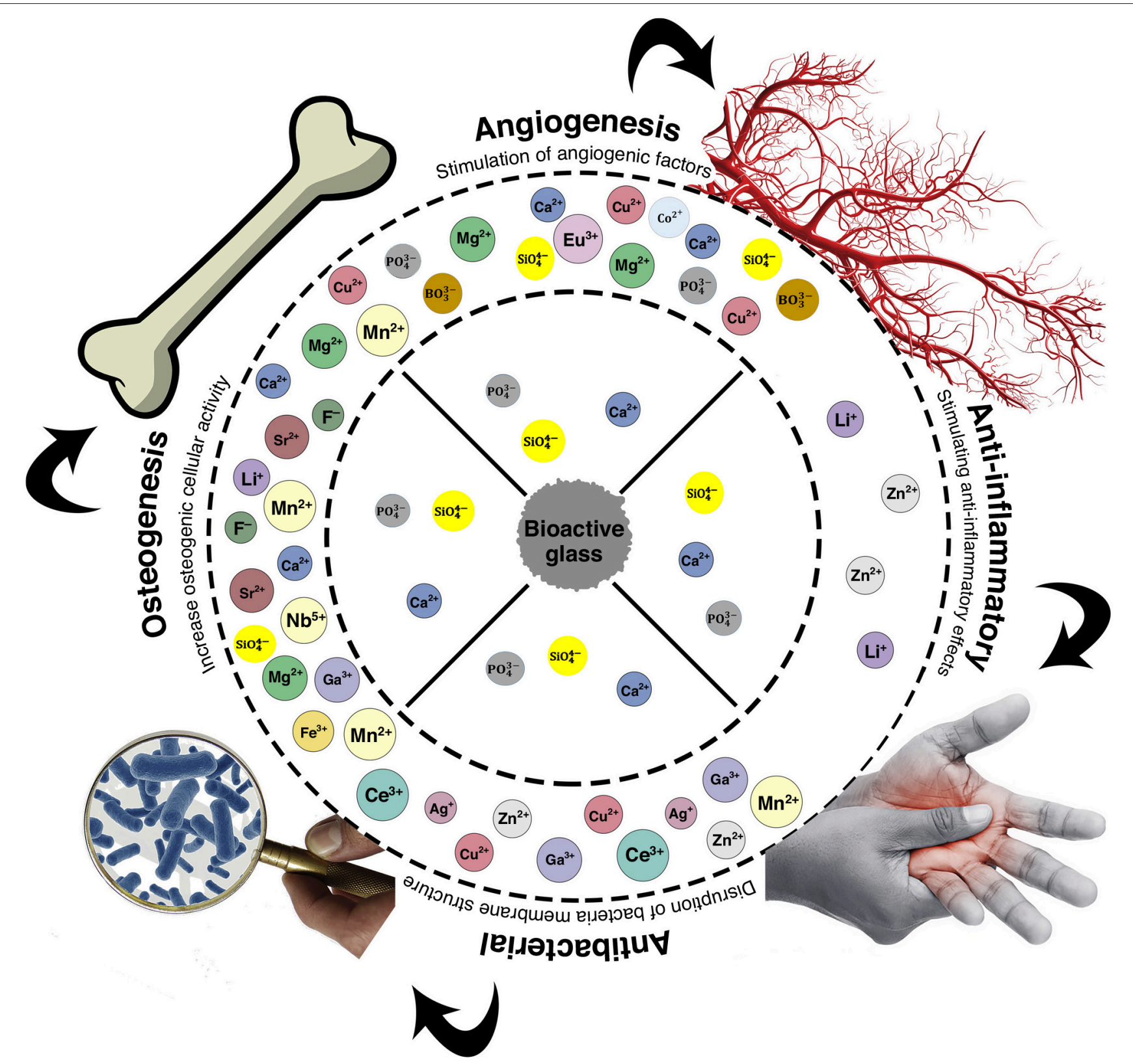

FIGURE 2 | The biological effects of BGs are related to the release of therapeutic ions from their structure into the surrounding environment. Reproduced with some modifications from Kargozar et al. (2018a).

(Day and Boccaccini, 2005). Moreover, there is a hope to improve the anti-inflammatory effects of BGs through doping with some specific ions (e.g., $\mathrm{Zn}^{2+}$ and $\mathrm{Li}^{+}$).

From the antibacterial point of view, it has been shown that BGs can decrease the risk of infections caused by both Gram-positive and Gram-negative strains (Liu et al., 2016a,b; Ottomeyer et al., 2016). This decrease can be achieved through two mechanisms (usually combined) regulated by the dissolution of BGs, including (i) the local increase of $\mathrm{pH}$ values in the injured site (due to the delivery of alkaline cations such as $\mathrm{Ca}^{2+}$ and $\mathrm{Na}^{+}$) and (ii) the release of antibacterial ions (e.g., silver, copper, zinc, cerium, and gallium) (Ratha et al., 2018; Bauer et al., 2019; Wajda et al., 2019). However, it has been documented that the effect of $\mathrm{pH}$ depends on the species of bacteria involved. For example, Wiegand et al. showed that $S$. aureus exhibits an increased sensitivity against silver nitrate with rising $\mathrm{pH}$ while $P$. aeruginosa exhibits a decreased sensitivity (Wiegand et al., 2015). In order to illustrate the potential suitability of BGs in the specific context of burn injuries, Gholipourmalekabadi et al. compared the antibacterial activity of silver- and fluoride-containing BGs vs. commonly-used antibiotics on multidrug-resistant bacterial 
TABLE 3 | Potential capability of BGs to meet the criteria required for burn management.

\begin{tabular}{|c|c|c|}
\hline Properties & Notes & References \\
\hline Attenuation of inflammation & Promising results in the general context of wound healing & $\begin{array}{l}\text { Day and Boccaccini, 2005; Varmette et al., } \\
2009\end{array}$ \\
\hline Prevention/treatment of infection & $\begin{array}{l}\text { Convincing results in the general context of soft tissue healing. One study has } \\
\text { been reported in the context of burn management, showing the efficacy of BGs } \\
\text { against multidrug-resistant bacterial strains typical of human infected burns. }\end{array}$ & Gholipourmalekabadi et al., 2016 \\
\hline Promotion of angiogenesis & Convincing results in the general context of bone tissue and soft tissue healing. & $\begin{array}{l}\text { Lin et al., 2012, 2016b; Quinlan et al., 2015; Li } \\
\text { et al., 2016a; Kargozar et al., 2018b }\end{array}$ \\
\hline Removal of exudates & $\begin{array}{l}\text { No evidence of that has been reported yet. This property is peculiar of MBGs } \\
\text { and is believed to be possible due to the highly-porous texture of MBGs. }\end{array}$ & Gholipourmalekabadi et al., 2016 \\
\hline Re-epithelization & Promising results in the context of tissue engineering. & Wang et al., 2017 \\
\hline
\end{tabular}

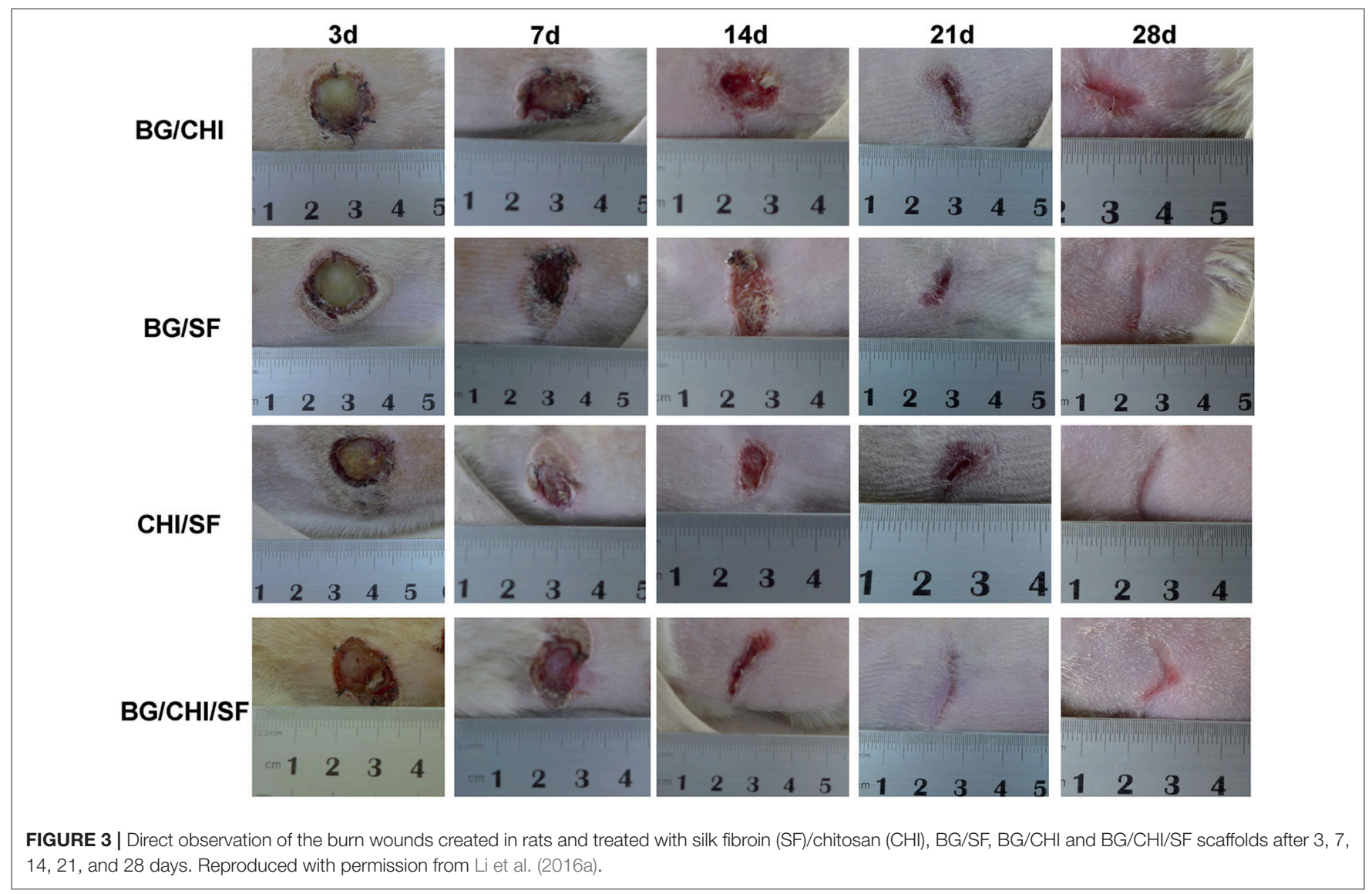

strains (K. pneumonia, S. aureus, E. coli, and P. aeruginosa) isolated from patients with burns (Gholipourmalekabadi et al., 2016). Their results revealed that, although fluoride-doped BGs did not show any antibacterial activity against the tested bacteria, BGs doped with 1 and $2 \%$ of silver significantly inhibited the bacterial growth in vitro in all cases (inhibition zone up to 11 $\pm 1 \mathrm{~mm}$ ). On the basis of this early experimental evidence, they concluded that silver-doped BGs could play an important role in the prevention of burn-associated infections, reduction of pain, and removal of excessive exudates. The capability of removing exudates is of great importance since they can fail the dressing to stick to the injured tissues and subsequently disrupt the wound healing process.
At present, other specific studies dealing with the efficacy of BGs against the typical bacteria of infected burns are not available in the literature; however, the potential suitability of BGs for the management of burns can be supported by other results from "general" wound healing applications.

The formulation of BGs for use in wound injuries (and hence in burns) is of paramount importance. In this regard, Lin et al. prepared BG ointments by mixing $58 \mathrm{~S}$ sol-gel BG micro-particles (SGBG-58S), 58S nano-BG (NBG-58S) and meltderived 45S5 BG (45S5) powder with Vaseline (V) at 18 wt.\% (Lin et al., 2012). They used this formulation for the treatment of full-thickness skin wounds in both normal and diabetic rats, whose injuries did not heal under conventional treatment. The 


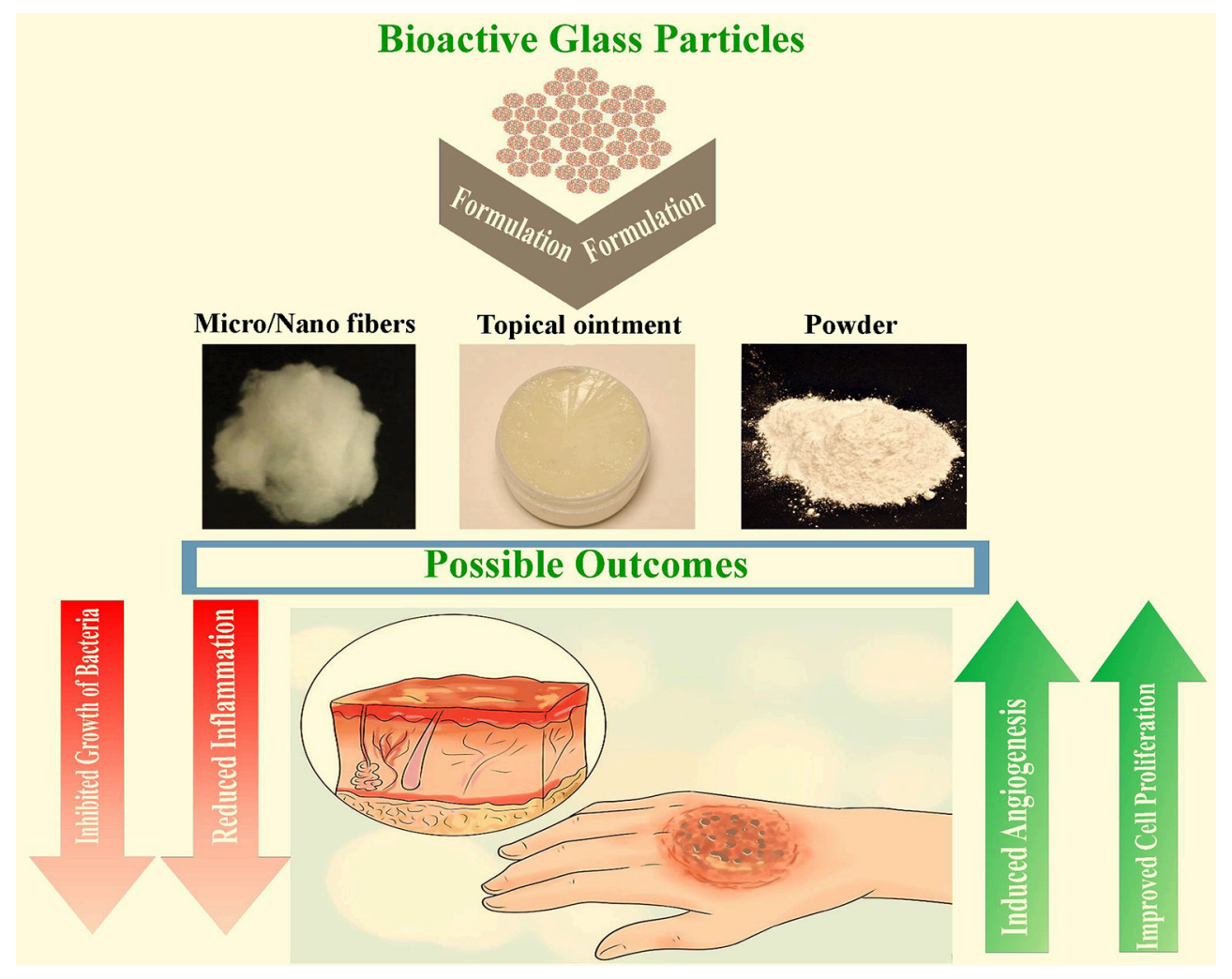

FIGURE 4 | Schematic representation of possibilities of BGs for the treatment of burns. With some modifications from Homayoon (2015).

obtained data revealed that all the compositions could accelerate the wound healing as a result of improving the proliferation of fibroblasts and growth of granulation tissue as well as the induction of angiogenesis. In addition to the susceptibility to infections, destruction of the vascular supply to the burned skin is one of the main barriers to the repair of injured tissue (Guo et al., 2011). Hence, improving angiogenesis regulated by BGs can be considered as a promising point regarding burn healing. The release of specific metal ions (e.g., copper and cobalt) from BGs into the surrounding environment can promote angiogenesis via hypoxia-mimicking pathways (Quinlan et al., 2015; Lin et al., 2016b; Balasubramanian et al., 2017; Kargozar et al., 2018b). Angiogenesis is vital to allow and/or accelerate the healing of burn wounds. On this matter, Li et al. developed $\mathrm{BG} /$ chitosan/silk fibroin composite scaffolds for the regeneration of deep burn wounds (Li et al., 2016a). The authors used these components with three specific and distinct aims: BG was included for inducing angiogenesis, chitosan for promoting the adsorption and enrichment of growth factors, and silk fibroin for providing a three-dimensional (3D) porous structure and mechanical support. Their results showed that adding BGs to the composites was the key to promote the formation and maturation of new blood vessels, which can significantly accelerate the wound healing process (see Figure 3).

Looking at the future and considering the peculiar properties that a biomaterial in contact with burns should exhibit, MBGs doped with therapeutic ions (see Table 2) could be regarded as ideal candidates being capable to act as multifunctional systems eliciting a local antibacterial effect and promoting angiogenesis, which are both crucial features required for the successful management of burns; furthermore, their highlyporous structure could be useful in adsorbing burn exudates.

As a further promising point, the sustained release of bioactive molecules that can be potentially effective in burn healing [e.g., epidermal growth factor (EGF)] via MBGs has been previously carried out; however, those studies were addressed to another application, i.e., the acceleration of bone regeneration (Wang et al., 2017).

\section{IMPLICATIONS AND CONCLUSIONS}

The impact of using BGs for the management of burns would be highly significant from multiple viewpoints including scientific, clinical, commercial, and socio-economical aspects. Specifically, MBGs show great promise due to their exceptional processing versatility and capability of acting as multifunctional platforms for the local release of therapeutic ions and biomolecules( $\mathrm{Wu}$ and Chang, 2014), which could perform a synergistic action (e.g., anti-inflammatory, antibacterial and angiogenic effects) addressed to promote the healing of burn injuries (see Figure 4). From a clinical perspective, the use of therapeutic inorganic 

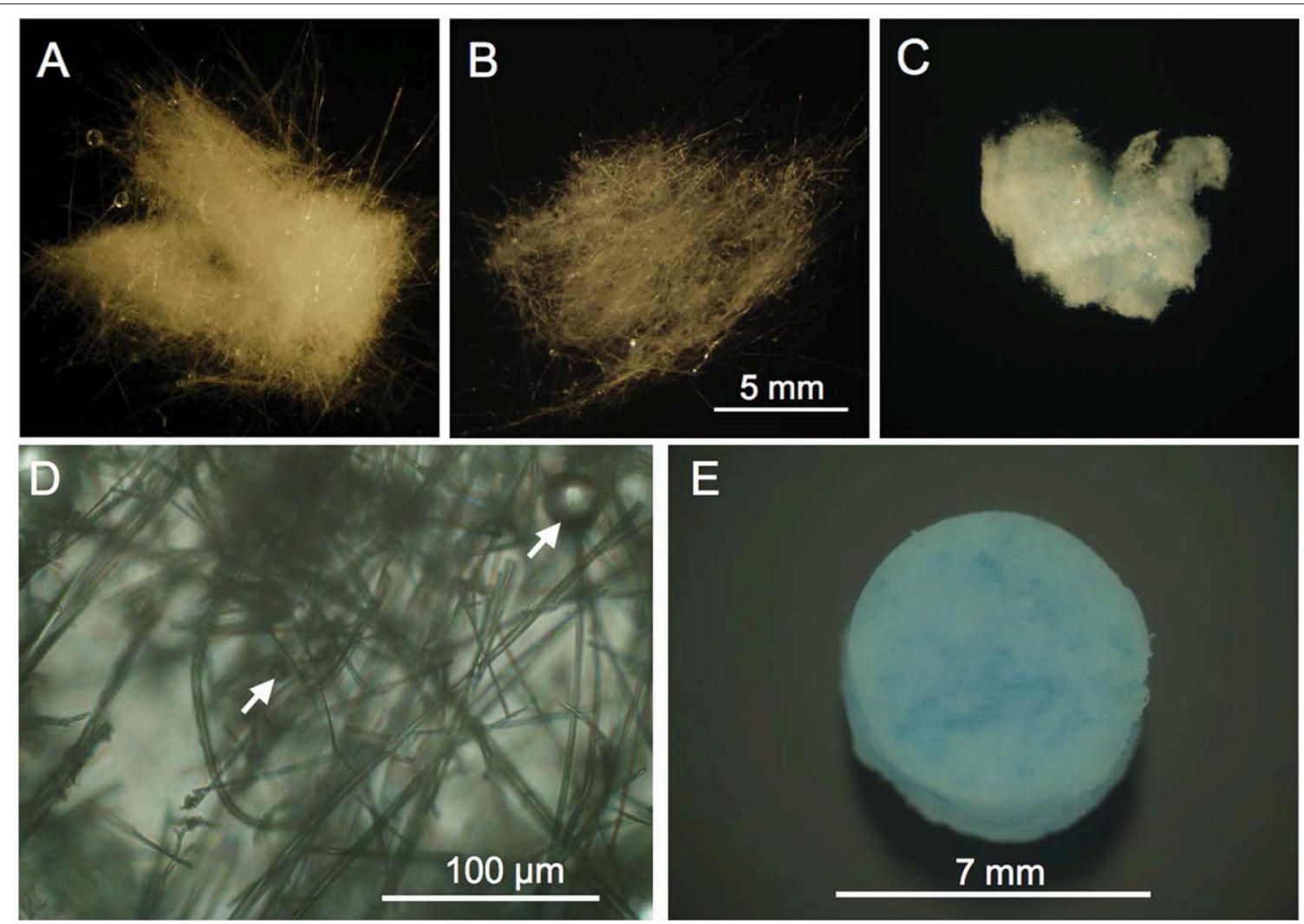

FIGURE 5 | Cotton-like fibrous scaffolds produced and implanted subcutaneously in rats including (A) 45S5 glass, (B) 13-93B3 glass, and (C) Cu-doped 13-93B3 glass; (D) higher magnification of the 13-93B3 glass microfibers with glass beads of variable size; (E) the mat of copper-containing 13-93B3 glass microfibers for implantation in rats (E). Images reproduced from Lin et al. (2014) with permission.

agents (i.e., ionic dissolution products) released from BGs or MBGs to treat burn-related infections could ideally allow overcoming the problem of resistant bacterial strains, which has been associated to the abuse of antibiotics in the last decades and is one of the grand challenges of the 21st century (Ventola, 2015). In fact, bacteria cannot be resistant to the effects of some inorganic cations, such as $\mathrm{Ag}^{+}$, that typically cause the disruption of the membrane after linking to the membrane proteins (Silvestry-Rodriguez et al., 2007).

From a commercial viewpoint, BG-based medical products intended for the treatment of burn injuries would be unique and highly novel. At present, no BG-based commercial medication is available for this specific purpose. There is also a paucity of BG-based commercial products for "general" wound healing. Cotton-candy $13-93 \mathrm{~B} 3$ borate $\mathrm{BG}\left(53 \mathrm{~B}_{2} \mathrm{O}_{3}-20 \mathrm{CaO}-12 \mathrm{~K}_{2} \mathrm{O}\right.$ $6 \mathrm{Na}_{2} \mathrm{O}-5 \mathrm{MgO}-4 \mathrm{P}_{2} \mathrm{O}_{5}$ wt.\%, trade-named as "Dermafuse") has been recently commercialized by Mo-Sci Corporation (USA) to accelerate wound healing in veterinary medicine and has also shown great promise for use in diabetic human patients suffering from chronic wounds (Wray, 2011). This material has a nanofibrous structure, so that blood platelets are trapped on the BG fibers that offer mechanical support and stability for tissue migration and the wound healing process. The fibers dissolve over time and form hydroxyapatite microspheres, to which blood vessels can attach. The antibacterial and proangiogenic properties of 13-93B3 BG formulation could justify the evaluation of this material for treating burn injuries, too. An evolution of this material was recently investigated by Lin et al. who successfully incorporates $\mathrm{Cu}^{2+}$ ions into 13-93B3 BGs microfibers and prepared wound dressings with an enhanced capability to stimulate angiogenesis, thereby significantly accelerating the healing of full-thickness skin defects in a rodent model (Lin et al., 2014) (Figure 5).

Appropriate in vitro and in vivo burn models should also be developed to test the suitability of BGs for this specific application; an overview of common testing methods is reported elsewhere (Qu and Nourbakhsh, 2017). It is stated that the method used to induce burns in experimental animals is, in fact, one of the most critical factors of clinical and ethical relevance; therefore, efforts should be made to reduce in vivo experiments to a minimum. In this regard, direct contact with a heated metal (usually created on the back of the animals) (Campelo et al., 2011), electricity (usually performed on large animals) (Zelt et al., 1988), and heated water (more widespread use) (Dahiya, 2009) are the commonly-used approaches to generate burn surfaces in experimental animal models (mouse, rat, pig, and monkey) (Abdullahi et al., 2014).

The selection of the most suitable form of application of BGs for burn care is another aspect deserving careful consideration. Surgeons typically claim an off-of-the-shelf and easy-to-use 
product that can fit the burn extension and homogeneously cover its surface. Three potential forms of application might be considered, i.e., fibrous BG constructs (such as the abovementioned "Dermafuse"), BG-containing ointments that could be easily spread topically and pliable composites (for example BG micro- or nano-inclusions embedded in a soft polymeric sheet or gel) (Kargozar et al., 2018e). The feasibility of all these potential products has already been reported in the biomaterials literature or industry, although in other contexts than burn care: thus, no particular problems are expected to arise from a processing viewpoint due to the great "technological" versatility of BGs.

Last but not least, given the absence of biomolecules (drugs) incorporated in this new product for the treatment of burn injuries, the regulatory procedure required

\section{REFERENCES}

Abdullahi, A., Amini-Nik, S., and Jeschke, M. (2014). Animal models in burn research. Cell. Mol. Life Sci. 71, 3241-3255. doi: 10.1007/s00018-014-1612-5

Abou Neel, E., Ahmed, I., Pratten, J., Nazhat, S., and Knowles, J. (2005). Characterisation of antibacterial copper releasing degradable phosphate glass fibres. Biomaterials 26, 2247-2254. doi: 10.1016/j.biomaterials.2004.07.024

Association, A. B. (2016). National Burn Repository 2015 Report Version 11.0. 2015. Chicago, IL: American Burn Association.

Australian and NZB Association. (2002). Emergency Management of Severe Burns Manual. Sydney: The Education Committee of the Australian and New Zealand Burns Association, Ltd.

Baino, F., Fiume, E., Barberi, J., Kargozar, S., Marchi, J., Massera, J., et al. (2019). Processing methods for making porous bioactive glass-based scaffolds-A state-of-the-art review. Int. J. Appl. Ceramic Technol. 1-35. doi: 10.1111/ijac.13195

Baino, F., Hamzehlou, S., and Kargozar, S. (2018). Bioactive glasses: where are we and where are we going? J. Funct. Biomater. 9:25. doi: 10.3390/jfb9010025

Baino, F., Novajra, G., Miguez-Pacheco, V., Boccaccini, A. R., and Vitale-Brovarone, C. (2016). Bioactive glasses: special applications outside the skeletal system. J. Non-Crystalline Solids 432, 15-30. doi: 10.1016/j.jnoncrysol.2015.02.015

Balasubramanian, P., Hupa, L., Jokic, B., Detsch, R., Grünewald, A., and Boccaccini, A. R. (2017). Angiogenic potential of boron-containing bioactive glasses: in vitro study. J. Mater. Sci. 52, 8785-8792. doi: 10.1007/s10853-016-0563-7

Barajas-Nava, L. A., López-Alcalde, J., Roqué i Figuls, M., Solà, I., and Bonfill Cosp, X. (2013). Antibiotic prophylaxis for preventing burn wound infection. Cochr Database Syst Rev. CD008738. doi: 10.1002/14651858.CD008738.pub2

Barnea, Y., Weiss, J., and Gur, E. (2010). A review of the applications of the hydrofiber dressing with silver (Aquacel $\left.\mathrm{Ag}^{\circledR}\right)$ ) in wound care. Therapeut. Clin. Risk Manag. 6:21. doi: 10.2147/TCRM.S3462

Barsoumian, A., Sanchez, C. J., Mende, K., Tully, C. C., Beckius, M. L., Akers, K. S., et al. (2013). In vitro toxicity and activity of Dakin's solution, mafenide acetate, and amphotericin B on filamentous fungi and human cells. J. Orthopaedic Trauma 27, 428-436. doi: 10.1097/BOT.0b013e3182830bf9

Bauer, J., Silva e Silva, A., Carvalho, E. M., Ferreira, P. V. C., Carvalho, C. N., Manso, A. P. et al. (2019). Dentin pretreatment with 45S5 and niobophosphate bioactive glass: Effects on $\mathrm{pH}$, antibacterial, mechanical properties of the interface and microtensile bond strength. J. Mech. Behav. Biomed. Mater. 90, 374-380. doi: 10.1016/j.jmbbm.2018.10.029

Bloemsma, G., Dokter, J., Boxma, H., and Oen, I. (2008). Mortality and causes of death in a burn centre. Burns 34, 1103-1107. doi: 10.1016/j.burns.2008.02.010

Branski, L. K., Al-Mousawi, A., Rivero, H., Jeschke, M. G., Sanford, A. P., and Herndon, D. N. (2009). Emerging infections in burns. Surg. Infect. 10, 389-397. doi: $10.1089 /$ sur.2009.024

Brown, M., and Wood, S. M. (1972). Relation between cation and lipid content of cell walls of Pseudomonas aeruginosa, Proteus vulgaris and Klebsiella aerogenes for clinical approval and use is expected not to be a tremendously draining and resource-consuming path, so that a large number of patients can benefit soon from these achievements.

\section{DATA AVAILABILITY}

All datasets generated for this study are included in the manuscript and the supplementary files.

\section{AUTHOR CONTRIBUTIONS}

SK: writing the first draft; MM: revision; SH: preparation of Figures and Tables; FB: final revision.

and their sensitivity to polymyxin B and other antibacterial agents. J. Pharm. Pharmacol. 24, 215-218. doi: 10.1111/j.2042-7158.1972.tb08967.x

Campelo, A. P. B. S., Campelo, M. W. S., Britto, G. A. d. C., Ayala, A. P., Guimarãe, S. B., and Vasconcelos, P. R. L. d. et al. (2011). Vasconcelos. An optimized animal model for partial and total skin thickness burns studies. Acta Cirurgica Brasileira 26, 38-42. doi: 10.1590/S0102-86502011000700008

Chalekson, C. P., Neumeister, M. W., and Jaynes, J. (2002). Improvement in burn wound infection and survival with antimicrobial peptide D2A21 (Demegel). Plastic Reconstruct. Surg. 109, 1338-1343. doi: 10.1097/00006534-200204010-00020

Chigurupati, S., Mughal, M. R., Okun, E., Das, S., Kumar, A., McCaffery, M., et al. (2013). Effects of cerium oxide nanoparticles on the growth of keratinocytes, fibroblasts and vascular endothelial cells in cutaneous wound healing. Biomaterials 34, 2194-2201. doi: 10.1016/j.biomaterials.2012.11.061

Coraça-Huber, D. C., Fille, M., Hausdorfer, J., Putzer, D., and Nogler. M. (2014). Efficacy of antibacterial bioactive glass S53P4 against S. aureus biofilms grown on titanium discs in vitro. J. Orthop. Res. 32, 175-177. doi: 10.1002/jor.22463

Dahiya, P. (2009). Burns as a model of SIRS. Front. Biosci. 14, 4962-4967. doi: $10.2741 / 3580$

Dai, T., Tegos, G. P., Burkatovskaya, M., Castano, A. P., Hamblin, M. R., et al. (2009). Chitosan acetate bandage as a topical antimicrobial dressing for infected burns. Antimicrobial. Agents Chemother. 53, 393-400. doi: 10.1128/AAC.00760-08

Dai, T. Y., Huang, Y. K., Sharma, S. T., Hashmi, J. B., Kurup, D., and Hamblin, M. R. (2010). Topical antimicrobials for burn wound infections. Recent Patents Anti-Infect Drug Discov. 5, 124-151. doi: 10.2174/157489110791233522

Dashnyam, K. G., Jin, Z. J., Kim, H., Perez, R., J., Jang, H., and Kim, H. W. (2017). Promoting angiogenesis with mesoporous microcarriers through a synergistic action of delivered silicon ion and VEG. Biomaterials F. 116, 145-157. doi: 10.1016/j.biomaterials.2016.11.053

Davan, R., Prasad, R., Jakka, V. S., Aparna, R., Phani, A., Jacob, B., et al. (2012). Cerium oxide nanoparticles promotes wound healing activity in in-vivo animal model. J. Bionanosci. 6, 78-83. doi: 10.1166/jbns.2012.1074

Day, R. M., and Boccaccini, A. R. (2005). Effect of particulate bioactive glasses on human macrophages and monocytes in vitro. J. Biomed. Mater. Res. Part A. 73, 73-79. doi: 10.1002/jbm.a.30262

Demirci, S., Dogan, A., Aydin, S., Dülger, E. Ç., and Sahin, F. (2016). Boron promotes streptozotocin-induced diabetic wound healing: roles in cell proliferation and migration, growth factor expression, and inflammation. Mol. Cel. Biochem. 417, 119-133. doi: 10.1007/s11010-016-2719-9

Deters, A., Schnetz, E., Schmidt, M., and Hensel, A. (2003). Effects of zinc histidine and zinc sulfate on natural human keratinocytes. Compl. Med. Res. 10, 19-25. doi: $10.1159 / 000069903$

Epand, R. M., Epand, R. F., andSavage, P. B. (2008). Ceragenins (cationic steroid compounds), a novel class of antimicrobial agents. Drug News Perspect. 21, 307-311. doi: 10.1358/dnp.2008.21.6.1246829

Fong, J., and Wood, F. (2006). Nanocrystalline silver dressings in wound management: a review. Int. J. Nanomed. 1, 441. doi: 10.2147/nano.2006.1.4.441 
Fox, C. L. (1968). Silver sulfadiazine-a new topical therapy for pseudomonas in burns: therapy of pseudomonas infection in burns. Arch. Surg. 96, 184-188. doi: 10.1001/archsurg.1968.01330200022004

Galeano, M., Altavilla, D., Bitto, A., Minutoli, L., Calò, M., Cascio, P., et al. (2006). Recombinant human erythropoietin improves angiogenesis and wound healing in experimental burn wounds. Crit. Care Med. 34, 1139-1146. doi: 10.1097/01.CCM.0000206468.18653.EC

Ganz, T. (2009). Defensins: antimicrobial peptides of innate immunity. Nat. Rev. Immunol. 3, 710X. doi: 10.1038/nri1180

Gargiulo, N., Cusano, A. M., Causa, F., Caputo, D., and Netti, P. A. (2013). Silvercontaining mesoporous bioactive glass with improved antibacterial properties. J. Mater. Sci. Mater. Med. 24, 2129-2135. doi: 10.1007/s10856-013-4968-4

Gholipourmalekabadi, M., Sameni, M., Hashemi, A., Zamani, F., Rostami, A., and Mozafari, M. (2016). Silver-and fluoride-containing mesoporous bioactive glasses versus commonly used antibiotics: activity against multidrug-resistant bacterial strains isolated from patients with burns. Burns 42, 131-140. doi: 10.1016/j.burns.2015.09.010

Guo, R., Xu, S., Ma, L., Huang, A., and Gao, C. (2011). The healing of full-thickness burns treated by using plasmid DNA encoding VEGF-165 activated collagen-chitosan dermal equivalents. Biomaterials 32, 1019-1031. doi: 10.1016/j.biomaterials.2010.08.087

Haynes, B. W. (1971). Mafenide acetate in burn treatment. N. Engl. J. Med. 284, 1324-1324. doi: 10.1056/NEJM197106102842310

Homayoon, B. (2015). "How to treat a burn," in wikiHow.

Hu, H., Tang, Y., Pang, L., Lin, C., Huang, W., Wang, D., et al. (2018). Angiogenesis and full-thickness wound healing efficiency of a copper-doped borate bioactive Glass/Poly(lactic-co-glycolic acid) Dressing Loaded with Vitamin E in vivo and in vitro. ACS Appl. Mater. Interfaces 10, 22939-22950. doi: 10.1021/acsami.8b04903

Hyland, E. J., Connolly, S. M., Fox, J. A., and Harvey, J. G. (2015). Minor burn management: potions and lotions. Aust. Prescr. 38, 124-127. doi: 10.18773/austprescr.2015.041

Jacobsen, F., Mittler, D., Hirsch, T., Gerhards, A., Lehnhardt, M., Voss, B., et al. (2005). Transient cutaneous adenoviral gene therapy with human host defense peptide hCAP-18/LL-37 is effective for the treatment of burn wound infections. Gene Therap. 12, 1494. doi: 10.1038/sj.gt.3302568

Jia, T. B., Chen, J. Y., Feng, X., and Chang, J. (2011). Fabrication and characterization of chitosan/mesoporous bioactive glasses porous films. J. Clin. Rehabil. Tissue Eng. Res. 15, 7877-7880. doi: 10.3969/j.issn.1673-8225.2011.42.021

Johari, B., Kadivar, M., Lak, S., Gholipourmalekabadi, M., Urbanska, A. M., Mozafari, M et al. (2016). Osteoblast-seeded bioglass/gelatin nanocomposite: a promising bone substitute in critical-size calvarial defect repair in rat. Int. J. Arti. Org. 39, 524-533. doi: 10.5301/ijao.5000533

Johnson, B. A., Anker, H., and Meleney, F. L. (1945). Bacitracin: a new antibiotic produced by a member of the B. Subt. Group. Sci. 102, 376-377. doi: 10.1126/science.102.2650.376

Jørgensen, B., Price, P., Andersen, K. E., Gottrup, F., Bech Thomsen, N, Scanlon, E., et al. (2005). The silver-releasing foam dressing, contreet foam, promotes faster healing of critically colonised venous leg ulcers: a randomised, controlled trial. Int. Wound J. 2, 64-73. doi: 10.1111/j.1742-4801.2005.00084.x

Kargozar, S., Baino, F., Hamzehlou, S., Hill, R. G., and Mozafari, M. (2018a). Bioactive glasses entering the mainstream. Drug Discovery Today 23, 1700-1704. doi: 10.1016/j.drudis.2018.05.027

Kargozar, S., Baino, F., Hamzehlou, S., Hill, R. G., and Mozafari, M. (2018b). Bioactive glasses: sprouting angiogenesis in tissue engineering. Trends Biotechnol. 36, 430-444. doi: 10.1016/j.tibtech.2017.12.003

Kargozar, S., Baino, F., Hoseini, S. J., Hamzehlou, S., Darroudi, M., Verdi, J., et al. (2018c). Biomedical applications of nanoceria: new roles for an old player. Nanomedicine 13, 3051-3069. doi: 10.2217/nnm-2018-0189

Kargozar, S., Hamzehlou, S., and Baino, F. (2017a). Potential of bioactive glasses for cardiac and pulmonary tissue engineering. Materials 10:1429. doi: $10.3390 / \mathrm{ma1} 0121429$

Kargozar, S., Hamzehlou, S., and Baino, F. (2019). Can bioactive glasses be useful to accelerate the healing of epithelial tissues? Mater. Sci. Eng. C 97, 1009-1020. doi: 10.1016/j.msec.2019.01.028

Kargozar, S., Lotfibakhshaiesh, N., Ai, J., Mozafari, M., Brouki Milan, P., Hamzehlou, S., et al. (2017b). Joghataei. Strontium- and cobalt-substituted bioactive glasses seeded with human umbilical cord perivascular cells to promote bone regeneration via enhanced osteogenic and angiogenic activities. Acta Biomaterialia 58(Suppl. C), 502-514. doi: 10.1016/j.actbio.2017.06.021

Kargozar, S., Lotfibakhshaiesh, N., Ai, J., Samadikuchaksaraie, A., Hill, R. G., Shah, P. A., et al. (2016). Synthesis, physico-chemical and biological characterization of strontium and cobalt substituted bioactive glasses for bone tissue engineering. J. Non-Crystalline Solids 449, 133-140. doi: 10.1016/j.jnoncrysol.2016.07.025

Kargozar, S., Montazerian, M., Hamzehlou, S. H.,Kim, W., and Baino, F. (2018d). Mesoporous bioactive glasses: promising platforms for antibacterial strategies. Acta Biomaterialia 81, 1-19. doi: 10.1016/j.actbio.2018.09.052

Kargozar, S., and Mozafari, M. (2018). Nanotechnology and Nanomedicine: Start small, think big. Materials Today. Proc. 5(7, Part 3), 15492-15500. doi: 10.1016/j.matpr.2018.04.155

Kargozar, S., Mozafari, M., Hill, R. G., Brouki Milan, P., Taghi Joghataei, M., Hamzehlou, S. et al. (2018e). Synergistic combination of bioactive glasses and polymers for enhanced bone tissue regeneration. Mater. Today. Proc. 5, 15532-15539. doi: 10.1016/j.matpr.2018.04.160

Kawai, K., Larson, B. J., Ishise, H., Carre, A. L., Nishimoto, S., Longaker, M., et al. (2011). Calcium-based nanoparticles accelerate skin wound healing. PLoS ONE 6:e27106. doi: 10.1371/journal.pone.0027106

Kaygusuz, H., Torlak, E., Akin-Evingür, G., Özen, I., von Klitzing, R., and Erim, F. B. (2017c). Antimicrobial cerium ion-chitosan crosslinked alginate biopolymer films: a novel and potential wound dressing. Int. J. Biol. Macromol. 105, 1161-1165. doi: 10.1016/j.ijbiomac.2017.07.144

Keen, E. F., Robinson, B. J., Hospenthal, D. R., Aldous, W. K., Wolf, S. E., Chung, $\mathrm{K}$. K et al. (2010). Incidence and bacteriology of burn infections at a military burn center. Burns 36, 461-468. doi: 10.1016/j.burns.2009.10.012

Kornblatt, A. P., Nicoletti, V. G., and Travaglia, A. (2016). The neglected role of copper ions in wound healing. J. Inorgan. Biochem. 161, 1-8. doi: 10.1016/j.jinorgbio.2016.02.012

Krishnan, P., Frew, Q., Green, A., Martin, R., and Dziewulski, P. (2013). Cause of death and correlation with autopsy findings in burns patients. Burns 39, 583-588. doi: 10.1016/j.burns.2012.09.017

Lachiewicz, A. M., Hauck, C. G., Weber, D. J., Cairns, B. A., and van Duin, D. (2017), Bacterial infections after burn injuries: impact of multidrug resistance. Clin. Infect. Dis. 65, 2130-2136. doi: 10.1093/cid/cix682

Lansdown, A. B. (2002). Calcium: a potential central regulator in wound healing in the skin. Wound Repair Regener. 10, 271-285. doi: 10.1046/j.1524-475X.2002.10502.x

Lansdown, A. B., Mirastschijski, U., Stubbs, N., Scanlon, E., and Ågren, M. S. (2007). Zinc in wound healing: theoretical, experimental, and clinical aspects. Wound Repair Regener. 15, 2-16. doi: 10.1111/j.1524-475X.2006.00179.x

Li, D., Jiao, G., Zhang, W., Chen, X., Ning, R., and Du, C. (2016a). Hybrid scaffolding strategy for dermal tissue reconstruction: a bioactive glass/chitosan/silk fibroin composite. RSC Adv. 6, 19887-19896. doi: 10.1039/C5RA26871K

Li, H., He, J., Yu, H., Green, C. R., and Chang, J. (2016b). Bioglass promotes wound healing by affecting gap junction connexin 43 mediated endothelial cell behavior. Biomaterials 84, 64-75. doi: 10.1016/j.biomaterials.2016.01.033

Lin, C., Mao, C., Zhang, J., Li, Y., and Chen, X. (2012). Healing effect of bioactive glass ointment on full-thickness skin wounds. Biomed. Mater. 7:045017. doi: 10.1088/1748-6041/7/4/045017

Lin, Y., Brown, R. F., Jung, S. B., and Day, D. E. (2014). Angiogenic effects of borate glass microfibers in a rodent model. J. Biomed. Mater. Res. Part A. 102, 4491-4499. doi: 10.1002/jbm.a.35120

Lin, Y., Xiao, W., Bal, B. S., and Rahaman, M. N. (2016b). Effect of copperdoped silicate 13-93 bioactive glass scaffolds on the response of MC3T3-E1 cells in vitro and on bone regeneration and angiogenesis in rat calvarial defects in vivo. Mater. Sci. Eng. C, 67, 440-452. doi: 10.1016/j.msec.2016.05.073

Lin, Y. H., Hsu, W. S., Chung, W. Y., Ko, T. H., and Lin, J. H. (2016a). Silverbased wound dressings reduce bacterial burden and promote wound healing. Int. Wound J. 13, 505-511. doi: 10.1111/iwj.12467

Lineaweaver, W., McMorris, S., Soucy, D., and Howard, R. (1985). Cellular and bacterial toxicities of topical antimicrobials. Plastic Reconstruct Surg. 75, 394-396. doi: 10.1097/00006534-198503000-00016

Liu, J., Rawlinson, S. C., Hill, R. G., and Fortune, F. (2016a). Fluoride incorporation in high phosphate containing bioactive glasses and in vitro 
osteogenic, angiogenic and antibacterial effects. Dental Mater. 32, e221-e237. doi: 10.1016/j.dental.2015.12.013

Liu, J., Rawlinson, S. C., Hill, R. G., and Fortune, F. (2016b). Strontium-substituted bioactive glasses in vitro osteogenic and antibacterial effects. Dental Mater. 32, $412-422$.

Mârza, S. M., Magyari, K., Bogdan, S., Moldovan, M., Peştean, C., et al. (2019). Skin wound regeneration with bioactive glass-gold nanoparticles ointment. Biomed. Mat. 14:025011. doi: 10.1088/1748-605X/aafd7d

Malic, C. C., Karoo, R. O., S., Austin, O., and Phipps, A. (2007). Resuscitation burn card-A useful tool for burn injury assessment. Burns 33, 195-199. doi: 10.1016/j.burns.2006.07.019

Meaume, S., Vallet, D., Nguyen Morere, M., and Teot, L. (2005). Evaluation of a silver-releasing hydroalginate dressing in chronic wounds with signs of local infection. J. Wound Care 14, 411-419. doi: 10.12968/jowc.2005.14.9.26835

Miola, M., Pakzad, Y., Banijamali, S., Kargozar, S., Vitale-Brovarone, C., Yazdanpanah, A., et al. (2019). Glass-ceramics for cancer treatment: So close, or yet so far? Acta Biomaterialia 83, 55-70. doi: 10.1016/j.actbio.2018.11.013

Miola, M., and Verné, E. C. (2016). Vitale-Brovarone and F. baino. antibacterial bioglass-derived scaffolds. innovative synthesis approach and characterization. Int. J. Appl. Glass Sci. 7, 238-247. doi: 10.1111/ijag.12209

Monafo, W., Tandon, S., Ayvazian, V., Tuchschmidt, J., Skinner, A., and Deitz, F. (1976). Cerium nitrate: a new topical antiseptic for extensive burns. Surgery 80, 465-473.

Moyer, C. A., Brentano, L., Gravens, D. L., Margraf, HW., and Monafo, WW. (1965). Treatment of large human burns with $0.5 \%$ silver nitrate solution. Arch. Surg. 90, 812-867. doi: 10.1001/archsurg.1965.01320120014002

Munster, A. M. (1984). Treatment of invasive Enterobacter cloacae burn wound sepsis with topical nitrofurazone. J. Trauma 24, 524-525. doi: 10.1097/00005373-198406000-00010

Naseri, S., Lepry, W. C., and Nazhat, S. N. (2017). Bioactive glasses in wound healing: hope or hype? J. Mater. Chem. B. 5, 6167-74. doi: 10.1039/C7TB01221G

Orosz, C. G., Wakely, E., Bergese, S. D., VanBuskirk, A., and Erim, F. B. (1996). Prevention of murine cardiac allograft rejection with gallium nitrate: comparison with Anti-CD4 Monoclonal Antibody1. Transplantation 61, 783-791. doi: 10.1097/00007890-199603150-00019

Oryan, A., Alemzadeh, E., and Eskandari, M. H. (2018). Kefir accelerates burn wound healing through inducing fibroblast cell migration in vitro and modulating the expression of IL-1ss, TGF-ss1, and bFGF genes in vivo. Probiot. Antimicrobial Proteins, 1-13. doi: 10.1007/s12602-018-9435-6

Ottomeyer, M., Mohammadkah, A., Day, D., and Westenberg, D. J. (2016). Broadspectrum antibacterial characteristics of four novel borate-based bioactive glasses. Adv. Microbiol. 6, 776-787. doi: 10.4236/aim.2016.610076

Palmieri, T. L., and Greenhalgh, D. G. (2002). Topical treatment of pediatric patients with burns. Am. J. Clin. Dermatol. 3, 529-534. doi: 10.2165/00128071-200203080-00003

Pourshahrestani, S., Zeimaran, E., Kadri, N. A., Gargiulo, N., Samuel, S., Naveen, S. V., et al. (2016). Gallium-containing mesoporous bioactive glass with potent hemostatic activity and antibacterial efficacy. J. Mater. Chem. B. 4, 71-86. doi: 10.1039/C5TB02062J

Qu, M., and Nourbakhsh, M. (2017). Current experimental models of burns. Discovery Med. 23, 95-103.

Quinlan, E., Partap, S., Azevedo, M. M., Jell, G., Stevens, M., O’Brien, F. J., et al. (2015). Hypoxia-mimicking bioactive glass/collagen glycosaminoglycan composite scaffolds to enhance angiogenesis and bone repair. Biomaterials 52, 358-366. doi: 10.1016/j.biomaterials.2015.02.006

Rahaman, M. N., Day, D. E., Bal, B. S., Fu, Q., Jung, S. B., Bonewald, L. F et al. (2011). Bioactive glass in tissue engineering. Acta biomaterialia 7, 2355-2373. doi: 10.1016/j.actbio.2011.03.016

Ramenzoni, L. L., Weber, F. E., Attin, T., and Schmidlin, P. R. (2017). Cerium chloride application promotes wound healing and cell proliferation in human foreskin fibroblasts. Materials 10, 573. doi: 10.3390/ma10060573

Ratha, I., Adarsh, T., Anand, A., Sinha, P. K., Diwan, P., Annapurna, K., et al. (2018). In vitro bioactivity and antibacterial properties of bismuth oxide modified bioactive glasses. J. Mater. Res. 33, 178-190. doi: 10.1557/jmr.2017.442

Ren, H., Han, C., Zhang, R., Xu, Z., Meng, Z., Weng, H., et al. (2006). The antibacterial effect of cecropin B on Pseudomonas aeruginosa infection of wounds in mice. Zhonghua shao shang 22, 445-447.
Ribeiro, M. P., Espiga, A., Silva, D., Baptista, P., Henriques, J., Ferreira, C., et al. (2009). Development of a new chitosan hydrogel for wound dressing. Wound Repair Regener. 17, 817-824. doi: 10.1111/j.1524-475X.2009.00538.x

Romero-Sánchez, L. B., Marí-Beffa, M., Carrillo, P., Medina, M. Á.,and DíazCuenca, A. (2018). Copper-containing mesoporous bioactive glass promotes angiogenesis in an in vivo zebrafish model. Acta Biomaterialia 68, 272-285. doi: 10.1016/j.actbio.2017.12.032

Rostan, E. F., DeBuys, H. V., Madey, D. L., and Pinnell, S. R. (2002). Evidence supporting zinc as an important antioxidant for skin. Int. J. Dermatol. 41, 606-611. doi: 10.1046/j.1365-4362.2002.01567.x

Rowan, M. P., Cancio, L. C., Elster, E. A., Burmeister, D. M., Rose, L. F., Natesan, S., et al. (2015). Burn wound healing and treatment: review and advancements. Crit Care 19:243. doi: 10.1186/s13054-015-0961-2

Sawhney, C. (1989). Amniotic membrane as a biological dressing in the management of burns. Burns 15, 339-342. doi: 10.1016/0305-4179(89)90015-6

Sen, C. K., Khanna, S., Venojarvi, M., Trikha, P., Ellison, E., Hunt, T. K., et al. (2002). Copper-induced vascular endothelial growth factor expression and wound healing. Am. J. Physiol. Heart Circul. Physiol. 282, H1821-H1827. doi: 10.1152/ajpheart.01015.2001

Sevitt, S. (1979). A review of the complications of burns, their origin and importance for illness and death. J. Trauma. 19, 358-369. doi: 10.1097/00005373-197905000-00010

Sezer, A. D., Cevher, E., Hatipoglu, F., Ogurtan, Z., Baş, A., Akbuga, J., et al. (2008). Preparation of fucoidan-chitosan hydrogel and its application as burn healing accelerator on rabbits. Biol. Pharm. Bull. 31, 2326-2333. doi: $10.1248 / \mathrm{bpb} .31 .2326$

Sharma, B., Harish, D., Singh, V. P., and Bangar, S. (2006). Septicemia as a cause of death in burns: an autopsy study. Burns 32, 545-549. doi: 10.1016/j.burns.2006.02.008

Silvestry-Rodriguez, N., Sicairos-Ruelas, E. E., Gerba, C. P., and Bright, K. R. (2007). Silver as a disinfectant. Rev. Environ. Contam. Toxicol. 191, 23-45. doi: 10.1007/978-0-387-69163-3_2

Sinha, R., Agarwal, R., and Agarwal, M. (1997). Povidone iodine plus neosporin in superficial burns-a continuing study. Burns 23, 626-628. doi: 10.1016/S0305-4179(97)00069-7

Sirelkhatim, A., Mahmud, S., Seeni, A., Kaus, N. H. M., Ann, L., Bakhori, S. K., et al. (2015). Review on zinc oxide nanoparticles: antibacterial activity and toxicity mechanism. Nano-Micro Lett. 7, 219-242. doi: 10.1007/s40820-015-0040-x

Sommer, K., Sander, A. L., Albig, M., Weber, R., Henrich, D., Frank, J., et al. (2013). Delayed wound repair in sepsis is associated with reduced local pro-inflammatory cytokine expression. PLoS One 8:e73992. doi: 10.1371/journal.pone.0073992

Steinstraesser, L., Koehler, T., Jacobsen, F., Daigeler, A., Goertz, O., Langer, S., et al. (2008). Host defense peptides in wound healing. Mol. Med. 14, 528-537. doi: 10.2119/2008-00002.Steinstraesser

Thompson, M. G., Truong-Le, V., Alamneh, Y. A., Black, C., Anderl, J., Honnold, C. L., et al. (2015). Evaluation of gallium citrate formulations against a multidrug-resistant strain of Klebsiella pneumoniae in a murine wound model of infection. Antimicrob. Agents Chemother. 00882-15. doi: 10.1128/AAC.00882-15

Ueno, M., Lyons, B. L., Burzenski, L. M., Gott, B., Shaffer, D. J., Roopenian, D. C., et al. (2005). Accelerated wound healing of alkali-burned corneas in MRL mice is associated with a reduced inflammatory signature. Invest. Ophthalmol. Visual Sci. 46, 4097-4106. doi: 10.1167/iovs.05-0548

Varmette, E. A., Nowalk, J. R., Flick, L. M., and Hall, M. M. (2009). Abrogation of the inflammatory response in LPS-stimulated RAW 264.7 murine macrophages by $\mathrm{Zn}$-and $\mathrm{Cu}$-doped bioactive sol-gel glasses. J. Biomedical Mater. Res. Part A. 90, 317-325. doi: 10.1002/jbm.a.32098

Ventola, C. L. (2015). The antibiotic resistance crisis: part 1: causes and threats. Pharm. Therapeut. 40, 277-283.

Wajda, A., Goldmann, W. H., Detsch, R., Boccaccini, A. R., and Biswas, K. (2019). Influence of zinc ions on structure, bioactivity, biocompatibility and antibacterial potential of melt-derived and gel-derived glasses from $\mathrm{CaO}$ SiO2 system. J. Non-Crystal. Solids 511, 86-99. doi: 10.1016/j.jnoncrysol.2018. 12.040

Wang, T., Gu, Q., Zhao, J., Mei, J., Shao, M., Pan, Y., et al. (2015). Calcium alginate enhances wound healing by up-regulating the ratio of collagen types I/III in diabetic rats. Int. J. Clin. Exp. Pathol. 8:6636. 
Wang, X., Chen, W., Liu, Q., Gao, K., Wang, G., Gao, L., et al. (2017). Function and mechanism of mesoporous bioactive glass adsorbed epidermal growth factor for accelerating bone tissue regeneration. Biomed. Mater. 12:025020. doi: 10.1088/1748-605X/aa65d8

Wang, X., Cheng, F., Liu, J. J.-,Smått, H., Gepperth, D., Lastusaari, M., et al. (2016). Biocomposites of copper-containing mesoporous bioactive glass and nanofibrillated cellulose: biocompatibility and angiogenic promotion in chronic wound healing application. Acta Biomaterialia 46, 286-298. doi: 10.1016/j.actbio.2016.09.021

Wang, Y., Beekman, J., Hew, J., Jackson, S., Issler-Fisher, A. C., Parungao, R., et al. (2018). Burn injury: challenges and advances in burn wound healing, infection, pain and scarring. Adv. Drug Deliv. Rev. 123, 3-17. doi: 10.1016/j.addr.2017.09.018

Whitacre, C., Apseloff, G., Cox, K., Matkovic, V., Jewell, S., and Gerber, N. (1992). Suppression of experimental autoimmune encephalomyelitis by gallium nitrate. J. Neuroimmunol. 39, 175-181. doi: 10.1016/0165-5728(92)90186-O

Wiegand, C., Abel, M., Ruth, P., Elsner, P., and Hipler, U. C. (2015). pH influence on antibacterial efficacy of common antiseptic substances. Skin Pharmacol. Physiol. 28, 147-158. doi: 10.1159/000367632

Wray, P. (2011). Cotton candy'that heals. Am. Ceram. Soc. Bull. 90, 24-31.

$\mathrm{Wu}, \mathrm{C}$., and Chang, J. (2014). Multifunctional mesoporous bioactive glasses for effective delivery of therapeutic ions and drug/growth factors. J. Control. Release 193, 282-295. doi: 10.1016/j.jconrel.2014.04.026

Wu, C., Zhou, Y., Xu, M., Han, P., Chen, L., Chang, J., et al. (2013). Copper-containing mesoporous bioactive glass scaffolds with multifunctional properties of angiogenesis capacity, osteostimulation and antibacterial activity. Biomaterials 34, 422-433. doi: 10.1016/j.biomaterials.2012.09.066

Xynos, I. D., Edgar, A. J., Buttery, L. D., Hench, L. L., and Polak, J. M. (2000). Ionic products of bioactive glass dissolution increase proliferation of human osteoblasts and induce insulin-like growth factor II mRNA expression and protein synthesis. Biochem. Biophys. Res. Commun. 276, 461-465. doi: 10.1006/bbrc.2000.3503

Yu, H., Peng, J., Xu, Y., Chang, J., and Li, H. (2015). Bioglass activated skin tissue engineering constructs for wound healing. ACS Appl. Mater. Inter. 8, 703-715. doi: 10.1021/acsami.5b09853

Zelt, R. G., Daniel, R. K., Ballard, P. A., Brissette, Y., and Heroux, P. (1988). High-voltage electrical injury: chronic wound evolution. Plastic Reconst. Surg. 82, 1027-1041. doi: 10.1097/00006534-19881200000014

Zhang, D., Leppäranta, O., Munukka, E., Ylänen, H., Viljanen, M. K., Eerola, E., et al. (2010). Antibacterial effects and dissolution behavior of six bioactive glasses. J. Biomed. Mater. Res. Part A. 93, 475-483. doi: 10.1002/jbm.a.32564

Zhou, Y., Shi, M., Jones, J. R., Chen, Z., Chang, J., Wu, C. et al. (2017). Strategies to direct vascularisation using mesoporous bioactive glassbased biomaterials for bone regeneration. Int. Mater. Rev. 62, 392-414. doi: $10.1080 / 09506608.2016 .1266744$

Conflict of Interest Statement: The authors declare that the research was conducted in the absence of any commercial or financial relationships that could be construed as a potential conflict of interest.

Copyright (C) 2019 Kargozar, Mozafari, Hamzehlou and Baino. This is an open-access article distributed under the terms of the Creative Commons Attribution License (CC $B Y)$. The use, distribution or reproduction in other forums is permitted, provided the original author(s) and the copyright owner(s) are credited and that the original publication in this journal is cited, in accordance with accepted academic practice. No use, distribution or reproduction is permitted which does not comply with these terms. 